\title{
PENGUJIAN SIFAT MEKANIK KAYU MERBAU DARI DAERAH BOGOR JAWA BARAT
}

\author{
Fengky S. Yoresta ${ }^{1}$
}

\begin{abstract}
ABSTRAK
Penelitian ini bertujuan menentukan MOE, MOR, dan kuat tekan sejajar serat kayu Merbau. Penelitian dilakukan mengacu pada standar ASTM D 143-94 menggunakan mesin Instron berkapasitas 5 ton. Hasil penelitian menunjukkan bahwa MOE, MOR, dan kuat tekan sejajar serat kayu Merbau berturut-turut adalah $162728.43 \mathrm{~kg} / \mathrm{cm}^{2}, 1090.64 \mathrm{~kg} / \mathrm{cm}^{2}$, dan $605.42 \mathrm{~kg} / \mathrm{cm}^{2}$. Berdasarkan hasil penelitian, kayu Merbau dapat digolongkan kedalam kayu kelas kuat I PKKI 1961, sehingga dapat direkomendasikan untuk digunakan pada konstruksi berat seperti jembatan, serta balok dan kolom pada bangunan.
\end{abstract}

Kata kunci : MOE, MOR, kuat tekan sejajar serat, kayu Merbau

\section{PENDAHULUAN}

Peningkatan jumlah penduduk mengakibatkan kebutuhan kayu sebagai bahan konstruksi semakin bertambah. Namun disisi lain, ketersediaan kayu semakin hari kian terbatas. Permasalahan ini memaksa perlu adanya optimasi pemanfaatan kayu, terutama berkaitan dengan penggunaannya sebagai komponen struktural dan non-struktural bangunan. Hal ini guna memastikan tidak terjadi pemborosan dalam pemanfaatannya. Oleh karena itu informasi mengenai sifat-sifat dasar kayu menjadi sangat penting untuk diketahui.

Sifat mekanik kayu adalah parameter penting yang harus diketahui dalam kaitan pemanfaatannya sebagai material konstruksi. Sifat dasar tersebut akan digunakan dalam proses perhitungan desain struktural bangunan kayu. Sifat mekanik kayu diantaranya meliputi kuat tekan sejajar dan tegak lurus serat, kuat lentur (MOR), kekuatan tarik sejajar dan tegak lurus serat, kuat geser, dan ketahanan belah.

Sifat-sifat kayu dapat dipengaruhi oleh banyak faktor. Wahyu (2008) menyebutkan bahwa faktorfaktor alam seperti tempat tumbuh, umur, jenis kayu, letak dalam batang, dan diameter akan mempengaruhi sifat fisik maupun sifat mekanik kayu. Penelitian ini bertujuan menentukan sifatsifat mekanik kayu Merbau yang berasal dari daerah kabupaten Bogor Jawa Barat, yaitu berupa Modulus Elastisitas lentur (MOE), kuat lentur (MOR), dan kuat tekan sejajar serat. Bogor merupakan daerah di Indonesia yang memiliki intensitas curah hujan yang tinggi. Keadaan tersebut akan mempengaruhi karakteristik kayu yang tumbuh di daerah ini. Hasil penelitian ini diharapkan dapat memberikan tambahan informasi ilmiah mengenai sifat-sifat dasar kayu Merbau sehingga memudahkan dalam pemanfaatannya sebagai material konstruksi.

\footnotetext{
${ }^{I}$ 1Divisi Rekayasa dan Desain Bangunan Kayu Departemen Teknologi Hasil Hutan IPB, syfengky@gmail.com
} 


\section{METODE PENELITIAN}

\subsection{Waktu dan Tempat Penelitian}

Penelitian ini dilakukan selama 3 bulan, mulai dari Januari hingga Maret 2015. Pengujian sifat mekanis dilakukan di laboratorium Rekayasa dan Desain Bangunan Kayu, Departemen Hasil Hutan, Institut Pertanian Bogor (IPB).

\subsection{Bahan dan Alat}

Penelitian ini menggunakan kayu Merbau dengan Kadar Air (KA) 13,93\%. Kayu diperoleh dari daerah kabupaten Bogor, Jawa barat. Kayu yang dipilih harus bebas dari kerusakan/cacat kayu. Hal ini bertujuan untuk meminimalkan pengaruh kerusakan/cacat kayu terhadap nilai sifat mekanis.

\subsection{Pembuatan benda uji}

Dua bentuk pengujian dilakukan dalam penelitian ini, yaitu uji lentur dan uji tekan sejajar serat. Sebanyak 6 buah sampel uji disiapkan untuk masing-masing pengujian tersebut. Sampel balok kayu untuk uji lentur dan uji tekan sejajar serat tersebut dibuat dengan dimensi yang mengacu pada standar ASTM D 143-94.

\subsection{Pengujian sifat mekanis}

Pengujian lentur dan tekan sejajar serat dilakukan menggunakan mesin Instron berkapasitas 5 ton (Gambar 1). Sifat mekanis yang ditentukan terdiri dari Modulus Elastisitas lentur (MOE), Modulus of Rupture (MOR), dan kuat tekan sejajar serat ( $\sigma \mathrm{tk} / /)$. Besarnya nilai MOE, MOR, dan kuat tekan sejajar serat berturut-turut ditentukan menggunakan persamaan-persamaan berikut,

$$
\mathrm{MOE}=\frac{P L^{3}}{4 \Delta b h^{3}} \quad \mathrm{MOR}=\frac{3 P L}{2 b h^{2}} \quad \sigma_{\mathrm{tk}} / /=\frac{P}{A}
$$

dimana $\mathrm{P}$ adalah beban maksimum $(\mathrm{kg})$, A adalah luas bidang tekan $(\mathrm{cm} 2), \mathrm{L}$ adalah panjang bentang $(\mathrm{cm}), \mathrm{b}$ dan $\mathrm{h}$ adalah dimensi penampang $(\mathrm{cm})$, dan $\Delta$ adalah defleksi di tengah bentang $(\mathrm{cm})$. Khusus P pada persamaan (1) adalah beban pada kondisi elastis.

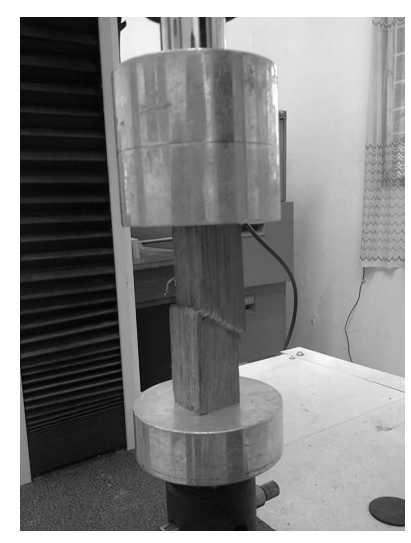

(a)

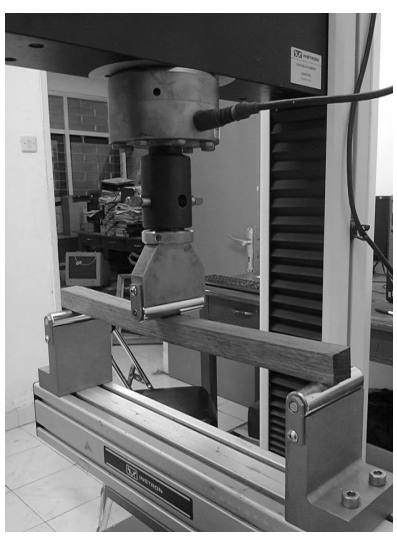

(b)

Gambar 1 Pengujian sifat mekanis kayu Merbau (a) uji lentur (b) uji tekan sejajar serat 


\section{HASIL DAN PEMBAHASAN}

Hasil pengujian lentur kayu Merbau terhadap 6 sampel uji diperlihatkan pada Tabel 1, sedangkan hasil pengujian tekan sejajar serat kayu tersebut disajikan pada Tabel 2.

Tabel 1 Hasil pengujian lentur kayu Merbau

\begin{tabular}{lllllll}
\hline No & $\begin{array}{l}\text { Lebar } \\
\text { sampel } \\
(\mathrm{cm})\end{array}$ & $\begin{array}{l}\text { Tebal } \\
\text { sampel } \\
(\mathrm{cm})\end{array}$ & $\begin{array}{l}\text { Defleksi } \\
\text { maksimum } \\
(\mathrm{mm})\end{array}$ & $\begin{array}{l}\text { Beban } \\
\text { maksimum } \\
(\mathrm{kg})\end{array}$ & $\begin{array}{l}\text { MOE } \\
\left(\mathrm{kg} / \mathrm{cm}^{2}\right)\end{array}$ & $\begin{array}{l}\text { MOR } \\
\left(\mathrm{kg} / \mathrm{cm}^{2}\right)\end{array}$ \\
\hline 1 & 2.49 & 2.49 & 10.58 & 298.07 & 132559.10 & 1044.79 \\
2 & 2.51 & 2.46 & 11.45 & 334.78 & 207577.55 & 1311.57 \\
\hline 3 & 2.59 & 2.59 & 12.45 & 346.21 & 195611.52 & 1233.17 \\
4 & 2.50 & 2.49 & 9.14 & 336.52 & 157701.32 & 1177.01 \\
\hline 5 & 2.46 & 2.46 & 11.95 & 329.18 & 152903.03 & 707.88 \\
6 & 2.42 & 2.51 & 8.42 & 300.73 & 130018.05 & 1069.42 \\
\hline Rata-rata & & 10.66 & 324.25 & 162728.43 & 1090.64 \\
\hline
\end{tabular}

Tabel 2 Hasil pengujian tekan sejajar serat kayu Merbau

\begin{tabular}{|c|c|c|c|c|c|}
\hline No & $\begin{array}{l}\text { Panjang } \\
(\mathrm{cm})\end{array}$ & sampel & Lebar sampel (cm) & Beban maksimum $(\mathrm{kg})$ & $\begin{array}{l}\text { Kuat tekan sejajar } \\
\text { serat, } \sigma_{\mathrm{tk}} / /\left(\mathrm{kg} / \mathrm{cm}^{2}\right)\end{array}$ \\
\hline 1 & 9.99 & & 5.02 & 3635.98 & 574.84 \\
\hline 2 & 10.89 & & 2.53 & 3982.93 & 625.35 \\
\hline 3 & 9.86 & & 2.45 & 3691.90 & 593.78 \\
\hline 4 & 10.02 & & 2.65 & 4155.96 & 591.81 \\
\hline 5 & 10.07 & & 2.58 & 4427.72 & 689.06 \\
\hline 6 & 10.58 & & 2.54 & 3597.27 & 557.66 \\
\hline \multicolumn{4}{|c|}{ Rata-rata } & 3915.29 & 605.42 \\
\hline
\end{tabular}

Kekuatan lentur (MOR) merupakan kapasitas maksimum suatu material dalam menahan beban lentur. Besarnya nilai kekuatan lentur suatu jenis kayu dipengaruhi oleh kadar airnya. Selama berada dibawah kondisi titik jenuh serat, kekuatan lentur dapat bertambah $4 \%$ pada setiap penurunan 1\% kadar air (Dolan, 2004). Tabel 1 memperlihatkan bahwa kekuatan lentur kayu Merbau berkisar antara $707.88 \mathrm{~kg} / \mathrm{cm}^{2}$ hingga $1311.57 \mathrm{~kg} / \mathrm{cm}^{2}$ dengan rata-rata sebesar 1090.64 $\mathrm{kg} / \mathrm{cm}^{2}$ (kadar air 13,93\%). Nilai ini lebih kecil dari kayu hitam/Ebony $\left(1656.22 \mathrm{~kg} / \mathrm{cm}^{2}\right.$ ) (Yoresta, 2015) dan Shorea leavifolia (1243.0 kg/cm²) (Chauf, 2005).

Nilai rata-rata kekuatan lentur kayu Merbau yang diperoleh dalam penelitian ini adalah sekitar 4.6\% lebih kecil dari nilai kuat lentur yang dikemukakan Supraptono (1995) untuk jenis kayu yang sama pada kadar air $12.27 \%$. Supraptono (1995) mengungkapkan, pada kadar air tersebut, nilai kekuatan lentur kayu Merbau berada pada kisaran $932.2 \mathrm{~kg} / \mathrm{cm}^{2}$ hingga $1466.0 \mathrm{~kg} / \mathrm{cm}^{2}$ dengan ratarata sebesar $1144.33 \mathrm{~kg} / \mathrm{cm}^{2}$.

Modulus Elastisitas (MOE) adalah kekakuan material yang direpresentasikan oleh kemiringan kurva P- $\Delta$ selama kondisi elastis. Nilai MOE kayu Merbau berada pada kisaran $130018.05 \mathrm{~kg} / \mathrm{cm}^{2}$ hingga $207577.55 \mathrm{~kg} / \mathrm{cm}^{2}$ dengan rata-rata sebesar $162728.43 \mathrm{~kg} / \mathrm{cm}^{2}$ seperti dicantumkan pada Tabel 1. Nilai ini jauh lebih besar dari nilai minimum MOE klasifikasi kelas kuat I PKKI 1961 $\left(125000 \mathrm{~kg} / \mathrm{cm}^{2}\right)$, serta sedikit lebih kecil dari Intsia bijuga $\left(167000 \mathrm{~kg} / \mathrm{cm}^{2}\right)$ (Martawijaya et.al., 
2005). Selain itu, nilai MOE rata-rata tersebut lebih besar 6.5\% dari nilai MOE rata-rata yang dikemukakan Supraptono (1995) untuk jenis kayu yang sama pada kadar air 12.27\%. Menurut Supraptono (1995), MOE kayu Merbau pada kadar air tersebut berada pada kisaran $77189.8 \mathrm{~kg} / \mathrm{cm}^{2}$ hingga $203809.5 \mathrm{~kg} / \mathrm{cm}^{2}$ dengan rata-rata $152709.7 \mathrm{~kg} / \mathrm{cm}^{2}$.

Kuat tekan sejajar serat adalah kapasitas maksimum kayu dalam menahan beban yang sejajar arah serat kayu. Pengujian tekan untuk menentukan tegangan harus menggunakan spesimen dengan rasio dimensi panjang kecil dari 11 (Wood Handbook, 2010). Hasil penelitian menunjukkan bahwa kayu Merbau memiliki kuat tekan sejajar serat berkisar antara $557.66 \mathrm{~kg} / \mathrm{cm}^{2}$ hingga $689.06 \mathrm{~kg} / \mathrm{cm}^{2}$ dengan rata-rata sebesar $605.42 \mathrm{~kg} / \mathrm{cm}^{2}$ seperti diperlihatkan pada Tabel 2. Besarnya nilai kuat tekan sejajar serat kayu juga dipengaruhi oleh kadar air. Nilai kuat tekan sejajar serat kayu, pada kadar air $15 \%$, berada pada kisaran $305.91 \mathrm{~kg} / \mathrm{cm}^{2}$ hingga $790.28 \mathrm{~kg} / \mathrm{cm}^{2}(30.0 \mathrm{~N} / \mathrm{mm} 2$ sampai 77.5 $\mathrm{N} / \mathrm{mm} 2$ ) (Duggal, 2008).

Nilai kuat tekan sejajar serat kayu Merbau yang diperoleh dalam penelitian ini adalah sekitar 14.4\% lebih kecil dari kuat tekan sejajar serat yang dikemukakan Supraptono (1995) untuk jenis kayu yang sama pada kadar air 12.75\%. Supraptono (1995) menyatakan nilai kuat tekan sejajar serat kayu Merbau pada kadar air $12.75 \%$ berada pada kisaran $620.0 \mathrm{~kg} / \mathrm{cm}^{2}$ hingga $910.6 \mathrm{~kg} / \mathrm{cm}^{2}$ dengan rata-rata sebesar $707.3 \mathrm{~kg} / \mathrm{cm}^{2}$. Berdasarkan nilai kuat tekan sejajar serat yang telah diperoleh tersebut, kayu Merbau berada pada kelas kuat I PKKI 1961.

\section{KESIMPULAN}

Berdasarkan hasil penelitian disimpulkan bahwa kayu Merbau tergolong kayu kelas kuat I berdasarkan PKKI 1961 dengan nilai rata-rata MOE, MOR, dan kuat tekan sejajar serat berturutturut adalah $162728.43 \mathrm{~kg} / \mathrm{cm}^{2}, 1090.64 \mathrm{~kg} / \mathrm{cm}^{2}$, dan $605.42 \mathrm{~kg} / \mathrm{cm}^{2}$. Kayu ini dapat digunakan untuk konstruksi berat seperti jembatan serta balok dan kolom pada bangunan.

\section{DAFTAR KEPUSTAKAAN}

[ASTM] American Society for Testing and Materials. Standard Methods for Testing Small Clear Specimens of Timber, ASTM : D143-94. West Conshohocken, Pennsylvania, USA.

[PKKI] Peraturan Konstruksi Kayu Indonesia. 1961. PKKI NI - 5 1961. Direktorat Jenderal Cipta Karya Departemen Pekerjaan Umum, Bandung.

Chauf KA. 2005. Karakteristik Mekanik Kayu Kamper sebagai Bahan Konstruksi. Majalah Ilmiah MEKTEK . Vol 7:41-47.

Dolan JD. 2004. Timber Structures. Pp 628-669 dalam Wai FC \& Eric ML (Eds) Handbook of Structural Engineering -2 nd ed. USA.

Duggal SK. 2008. Building Materials - 3rd ed. New Age International (P) Ltd, New Delhi.

Martawijaya A., Kartasujana I, Mandang YI, Prawira SA, \& Kadir K. 2005. Atlas Kayu Indonesia, Jilid II. Departemen Kehutanan, Badan Penelitian dan Pengembangan Kehutanan, Bogor.

Supraptono B. 1995. Sifat-sifat Fisik dan Mekanika dari Sebelas Jenis Kayu Non-Dipterocarps diPulau Buru. FRONTIR. Vol x(17):75-88

Wahyu, D dan Nugroho, M. 2008. Tinjauan Hasil-hasil penelitian faktor-faktor alam yang mempengaruhi sifat fisik dan mekanik kayu Indonesia. Jurnal Ilmu dan Teknologi Kayu Tropis. Masyarakat Peneliti Kayu Indonesia. Vol.5(1):85-10

Wood Handbook. 2010. Wood as Engineering Material. Forest Product Laboratory. United States Department of Agriculture Forest Service, Madison.

Yoresta FS. 2015. Physical and Mechanical Properties of Black Wood (Ebony) as a Construction Material. Jurnal Arsitektur Universitas Tanjungpura. Vol.2(1):22-28 